Vol. 06, No. 03; 2021

ISSN: $2456-8643$

\title{
COMPARATIVE ANALYSIS OF KNOWLEDGE GAPS IN THE UNIFIED AGRICULTURAL EXTENSION SERVICES IN THE THREE GEOPOLITICAL ZONES OF SOUTHERN NIGERIA
}

\author{
*S. Nwafor, **B. A. Odinwa and ***S. O. Olatunji \\ *Department of Agricultural, Ignatius Ajuru University of Education, Port Harcourt, Rivers State, Nigeria \\ **Department of Agricultural Education, Federal College of Education (Technical), PMB 11, Omoku, Rivers State, \\ Nigeria. \\ ***Department of Agricultural Economics and Extension, University of Port Harcourt, Rivers State, Nigeria
}

https://doi.org/10.35410/IJAEB.2021.5645

\begin{abstract}
The study compared the knowledge gaps in the unified agricultural extension services in three geopolitical zones of southern Nigeria. Two specific objectives were developed for the study. The study adopted descriptive survey research design and purposive sampling method was used to select one State, 2ADP zones and four ADP blocks from each of the 3 geopolitical zones of South-South, South-East, and South-West, making a total of 3 States, 6 ADP zones, 12 ADP blocks and 12 ADP cells. Simple random sampling technique was finally used to select 60 extension agents ( 5 from each cell), and 444 registered contact farmers (37 from each cell), which gave a total of five hundred and four (504) respondents and used for the study. Descriptive statistics such as weighted mean scores and inferential tool such as ANOVA were used for the analysis and test of significance, respectively. The finding of the study showed that professional operations in the Unified Agricultural Extension Services has improved the technological practices in the Southern geopolitical zones of Nigeria to a high extent $(\mathrm{GM}=3.03)$, but with more impact in the South-West $(\mathrm{M}=3.38)$ and South-East $(\mathrm{GM}=3.07)$ geopolitical zones. It also revealed that knowledge gaps do not exist in the operation of the Unified Agricultural Extension services in the three geopolitical zones ( $\mathrm{f}$-cal $=0.340$ and $\mathrm{f}$-crit $=3.28$ ). The study therefore, recommended that: 1) Professional operations in the Unified Agricultural Extension Services should be encouraged in the South-South geopolitical zone in order to be on the same page with the other zones in Nigeria. 2) Fortnight Training (FNT) sessions of the extension agents should be emphasized and properly monitored to achieve continuous uniformity in extension operation in the study areas, and 3) A unified extension package involving the State Ministries of Agriculture, non-governmental agro agencies, extension professionals and the farmers should be developed to encourage uniformity in extension method and service delivery in Nigeria.
\end{abstract}

Keywords: Unified Agricultural Extension Services , Three Geopolitical Zones Of Southern Nigeria.

\section{INTRODUCTION}

The priority of agricultural improvement in Nigeria is to be self sufficient in food production and delivery to consumption centres. Agricultural extension provides the avenue through which this 
Vol. 06, No. 03; 2021

ISSN: $2456-8643$

can be achieved. The word extension is described as a deliberate attempt by research using extension agents to get across knowledge in the form of education to enlighten the farm families on the best agricultural practices that supersedes their archaic methods of farming in order to aid them in taking on-farm decisions to meet their demands through the use of skill (science) in a pragmatic approach. Agricultural extension can also be viewed as a counsel and assistance rendered to the farmers and their family circle through enlightening consciousness and specific methods on new farming procedures and techniques in order to increase their farm yield and profit which in turn improves their standard of living.

According to Robert and Robert (2003) agricultural extension gives farmers the adequate scientific knowledge needed to proffer solution to their challenges. It was maintained that it is also one of the means of transformation, the purpose for transformation, the gain of transformation, the benefits you can get, the procedure by which the transformation is attained at and also the risk obtainable in this transformation. Adedoyin (2004) opined that technological advancement through research and technology are communicated via the services of extension and education which have been discovered as ultimate inputs essential for developing and sustaining productivity in agricultural sector. It was disclosed that high increased yields are the expected results of transformation endeavour, and extension impact would be revealed more in increased farm yields than in other steps. It also stated that research determination will have no direction of purpose unless the new innovation is acquired by the farmers. It went further to argue that the result of a new agricultural invention can only be easily reached to the farmers through the organized system of extension service. It was established that farmers have sufficient indigenous knowledge or native intelligence to concede those new innovations which are helpful and improves economic growth and in turn put together a rural people, contented of its appearance and capable of taking his responsibility professionally with a loving home and community in view. It was revealed that the whole essence of extension work is to win endorsement of farmers through scientific influence.

Asiabaka (2008) reported that extension is designed to win endorsement of the farmers with reference to the rate of alteration thus the massiveness of the farmers are said to be fully grown and are opposed to transformation with their subsequent challenges on agricultural advancement. It was stated that extension workers are under obligation to transmit the results of research to the farmers bearing in mind their standard of educational awareness which is a militating factor amongst the rural people in most African nations which have limited their agricultural productivity to that of their immediate family consumption and have deterred agricultural products been produced in commercial quantity quantifiable to the population thereby leading to food insecurity. It proclaimed that it is the sole duty of extension agents to communicate the outcome of research to farmers and thereby filling the message difference between the researchers and farmers and in turn convey farmers' production challenges to the research station for help which assist farmers to take a stand in their farm management. It was further reported that the extension agents also aid farmers make wise decisions using their available means to boost productivity and promote cultural values, entertainment, rational and spiritual life of the rural people. It was maintained that when a farmer neglects to take up an innovation, it is because he is yet to be persuaded of the advantages of the innovation. It concluded by saying that 
Vol. 06, No. 03; 2021

ISSN: $2456-8643$

whenever the farmers' sees the reward, they become curious to adopt the innovation because every farmer aims at achieving lofty yield in productivity beyond native intelligence via a new idea.

According to Agbor, Torima, and Imbur (2013), the perception of the fundamental roles of agriculture in the economic growth of the country as a major apprehension of the Federal Government of Nigeria among other issues prompted the establishment of agricultural programmes premeditated at encouraging agriculture after independence. This indeed makes up the large scope of extension programmes such as National Accelerated Food Production Project (NAFPP) ushered in (1972), Agricultural Development Projects, ADP (1975), the Accelerated Development Area Project, ADAP (1982), and Multi-State Agricultural Development Projects, MSADP (1986). Among other programmes that were introduced includes the Operation Feed the Nation, OFN (1976), the River Basin Development Authority, RBDA (1973), the Green Revolution Programme, GRP (1980), the national Directorate of Food, Roads and Rural Infrastructure, DFRRI (1996), the National Directorate of Employment, NDE (1986), the National Agricultural Insurance Scheme, NAIS (1987) and the National Fadama Development Project, NFDP (1992), the Poverty Alleviation Programme, PAP (2000), and National Economic Empowerment and Development Strategy, NEEDS (2004) that were initiated.

Obibuaku (1983) opined that some private agencies have equally ventured on agricultural extension services mostly ahead of a particular clientele system of their option. The agencies includes; multinational oil firms like Shell Petroleum Development Company, Nigerian Agip Oil Company limited, Total E \& P Petroleum, The Nigeria Tobacco Company, Religious Organization and Non-Governmental Organizations (NGOs). Kelsey and Hearne (1966) reported that some international organizations have also been engaged in agricultural extension and rural advancement programmes in Nigeria for over a period of time. Noteworthy among these are the World Bank, International Fund for Agricultural Development (IFAD), United State Agency for International Development (USAID), Technical Centre for Agricultural and Rural Cooperation (CTA), the last but not the least Food and Agriculture Organization (FAO) of the United Nations.

Garforth (2004) argues that most of the attempts by the agricultural extension programmes initiated by the government have been declared inefficient because of its inability to yield tangible results. It was disclosed that the bankruptcy of some of these attempts have been attributed to the incompetent agricultural extension systems applied in Nigeria and reiterated that large number of farmers did not acquire formal education and as such do not wish to take undue risk, and produces at marginal resources for subsisting grade using primitive tools with desirous demands of extension services.

Madukwe (1995) cited that the focus of attention was usually on export crops such as rubber, cotton, tea and sugar which was based on the technical advice that was provided to plantation managers and large landowners while little attention and assistance was given to small farmers who grew arable crops, except in times of crises. It was revealed that the various top-down extension systems was the order of the day and after independence, commodity-based extension services emerged from the remnants of the colonial system, with production targets established as part of five-year development plans. In addition, various schemes were initiated to meet the needs of small-scale farmers with support from foreign donors. Adedoyin (2004) stated that since 
Vol. 06, No. 03; 2021

ISSN: $2456-8643$

the nation's independence in 1960s, Nigeria has adopted several mechanisms in agricultural extension systems on how to improve on the traditional agricultural practices of the farmers who are predominantly peasants with or without knowledge of the new farm practices which evolves technological innovations. It was buttressed that in a bid to pursue and reduce poverty and food insecurity, the federal government also initiated some other agricultural extension programmes with the aim of increasing productivity of the farmers in view of boasting the nation's economy. Udiandeye (2017) asserted that there is no accomplishment in human effort without countervailing problems. It was mentioned that effective agricultural extension was bedeviled by chains of problems such as; lack of a single line of command, dilution of efforts by assigning too many jobs to extension workers; excessively large areas of operation without providing any logistic support, i.e., vehicle, lack of regular training for updating knowledge of extension workers; lack of research findings appropriate to condition of farmers field, low status and morale of extension staff and the duplications of services by various development departments.

It maintained that currently Agricultural Extension Department has quite a number of agencies and some NGOs that are anxious in agricultural extension activities. But despondently, there exists slight synchronization among these departments. The author proclaimed that there is no harm in identifying the dilemma areas by individual organization/agencies, but in any case a strong organization should subsist so as to make management efforts to determine those challenges.

The establishment of Agricultural Development Programmes (ADPs) in all states of the Federation in Nigeria rehabilitated extension services through the use of Training and Visit System $(\mathrm{T} \& \mathrm{~V})$ which was yet another means of curbing food insecurity in Nigeria. The T\&V extension system as described by Benor and Baxter (1984) is currently implemented in a unified version. This was in response to the National Council on Agriculture (NCA) meeting held at Maiduguri in 1990. Falusi and Olayide, (1980) and Idachaba (1980) posited that the use of the $\mathrm{T} \& \mathrm{~V}$ approach in reaching farmers recognized only the small-scale farmers as the focus for realizing the growth preferred in agriculture while Amalu (1998) argued that the Training and Visits (T\&V) extension system engaged by ADPs have been discredited and queried for keeping out stakeholders from involution in extension transfer systems.

According to Benor and Baxter (1984) Unified Agricultural Extension System (UAES) came on board in 1990 as pronounced by the National Council of Agriculture (NCA). It was maintained that the system in realistic expressions amounts to an alteration of the Training and Visit (T\&V) system in that it provides for extension delivery in all sectors of agriculture such as crops, livestock, fisheries, agro-forestry, soil and water conservation practices which are carried out by one Village Extension Agent (VEA) who is directly in contact with the farmer to unravel some of the recognized problems of the ministry-based extension, which was the reason $\mathrm{T} \& \mathrm{~V}$ was established. The authors reported that the $\mathrm{T} \& \mathrm{~V}$ system was meant to carry out some specific objectives such as to build a professional extension service that is capable of assisting farmers to raise production, increase their incomes and provide suitable support for agricultural development. It upheld that the key to achieving this objective is the conception of a vibrant link between famers, professional extension workers, input agencies and researchers. It was reported 
Vol. 06, No. 03; 2021

ISSN: $2456-8643$

that as a result, extension field staff is allocated moderately identical number of farmers which are their household tasks and they are given a work programme consisting of habitual visits to such farmers and predetermined dates for training. The $\mathrm{T} \& \mathrm{~V}$ system of agricultural extension is a professional system of extension based on frequently updated training of extension workers and regular field visit. The system operates through Management-By-Objectives (MBO), which concerns the optimization of human resources.

Nigeria is gifted with a commendable area of land that can be utilized effectively to provide all agricultural demands of the country and supply to her citizens promptly. The Nigerian population is yet another factor that can assist to boost agriculture. It has been discovered that over $50 \%$ of Nigeria's population (180 million) is jobless (National Bureau of Statistics, 2009). Given the facts on ground, Nigeria will be most excellent in the area of world food production if this massive manpower can be inclined toward agriculture. Unrelenting agricultural extension practice has been seen as a solution to all agricultural and technological problems of the developed nations of the world like United State of America, UK, Germany, etc. It is expected that third world countries should properly and practically embrace it (Odinwa, Isife \& Nlerum, 2019). Based on this, Nigeria has practiced several extension systems as mentioned earlier including, the Unified Agricultural Extension Services (UAES) which combines the essential features of the various extension systems, in order to solve the problem of food production throughout the country (Williams \& Fenley, 1984). Feder, Slade and Sundaram (1986) maintained that extension approach remains fundamentally top-down in approach and the farmers also still essentially remain passive receptors of information, which may not necessarily meet their needs while the generality must be informed by the need to remove the problems of conflicting messages to the clientele by multiple agents. It was also anticipated to make the scheme more gainful by eliminating replication of efforts.

In spite of all these brokers that appear to provide assistance to Nigerian agriculture, it is discouraging that Nigeria is still inactive and unable to produce adequate agricultural commodities to feed her population especially in some states in Nigeria. Why are there differences in food production among the states that have the same mandate of improving agricultural productivity in Nigeria? Why has Nigeria not been able to tackle food vulnerability with all the abundance of natural resources in the agricultural sector? Or could it be attributed to the professional operations associated with the Unified Agricultural Extension Services? It was in search of solutions to these heart rending questions and much more that this study was undertaken to evaluate the efficiency of the Unified Agricultural Extension Services in the three geopolitical zones in southern Nigeria and the knowledge gaps that exists in the study areas. Therefore, the two specific objectives of this study were to:

Assess the extent to which professional operations of Unified Agricultural Extension Services have improved agro practices in the three geopolitical zones of southern Nigeria.

Compare the knowledge gaps to effectiveness of the Unified Agricultural Extension Services in the three geopolitical zones in southern Nigeria.

Two hypotheses were formulated to direct the study, such as:

Ho: Professional operations of Unified Agricultural Extension Services in the three geopolitical zones of southern Nigeria do not differ significantly. 
Vol. 06, No. 03; 2021

ISSN: $2456-8643$

Ho: There is no significant difference in the knowledge gaps to the effectiveness of Unified Agricultural Extension Services among the three geopolitical zones under study.

\section{METHODOLOGY}

The study was carried out in three geo-political zones of southern Nigeria which includes the South-South, South-East and the South-West. Nigeria is a large country that has a different topography. The south is characterized with low lands that climb into hills and plateaus in the central point of the country. The southeast are naturally self-possessed with hills and valleys. The climate also differs from the south-south and south-west as tropical zones due to their location close to the equator. The country at large has a land area of 923,768sq.km (Kankara \& Darma, 2016). The massive land in the country is fertile for agriculture, industrial and commercial activities. The southern Nigeria farmers depend mainly on natural precipitation for agriculture. Descriptive survey design was adopted to examine a cross-section of the population of the extension agents of Agricultural Development Project (ADP), and farmers in the three southern geopolitical zones, for possible policy generation and economic intervention in the areas. Purposive sampling method was used to select one State, 2ADP zones and four ADP blocks from each of the 3 geopolitical zones of South-South, South-East, and South-West. The reason was to select States and zones that are very active in extension activities, which Ladele and Chah (2014) also recognized as a fast technique employed when one wishes to gain a quick insight into a social incident. Therefore, 3 States, 6 ADP zones and 12 ADP blocks and 12 ADP cells were purposively selected Finally, a simple random sampling technique, which removes bias by giving all persons an adequate opportunity to be chosen according to Moore and MacCabe (2006), was used to select 60 extension agents ( 5 from each cell), and 444 registered contact farmers (37 from each cell), which gave a total of five hundred and four (504) respondents and used for the study.

Primary data were collected through the administration of a structured questionnaire and interview schedules, designed in Likert rating scales of 5, 4, 3, 2 and1, which were summated to give a critical mean of 3.00 for judgment. Data collected were analyzed using inferential statistics such as weighted mean scores and the Analysis of Variance (ANOVA) to test the hypotheses for significance at probability level of 0.05 .

\section{RESULT AND DISCUSSION}

Extent to which professional operations of Unified Agricultural Extension Services have improved agro practices in the three geopolitical zones of southern Nigeria

The findings in Table 1, showed that professional operations in extension has improved technological practices in the Southern geopolitical zones of Nigeria $(\mathrm{GM}=3.07)$ with more impact in the South-West and South-East geopolitical zones $(M=3.48$ and $M=3.09)$ respectively. This shows that professional operations of extension are more effective in the South-West and South-East geopolitical zones. The result corroborates with the thoughts of Benor et al. (1984) who upheld that the key to achieving the objective is the conception of a vibrant link between famers, professional extension workers and researchers. Also, it showed that professional operations in extension has aided farmers in adoption of new technology (GM = $3.03)$, except in the South-South geopolitical zone ( $\mathrm{M}=2.63)$. 
However, the findings showed that professional operations in extension did not develop appropriate clue to solve identified problems $(\mathrm{GM}=2.98)$, except in south west and south east $(\mathrm{M}=3.48$ and $\mathrm{M}=3.02$ respectively). Also, it showed that professional extension did not bring about continuous and full training of extension workers in the entire southern Nigeria $(\mathrm{GM}=$ 2.97), except in south west and south east geopolitical zones $(\mathrm{M}=3.35$ and $\mathrm{M}=3.01$ respectively). These findings are in line with Unamma et al. (2004) who buttressed the fact that professionalism in Unified Agricultural Extension Services entails the ability of the extension worker at all levels to identify production constraints of farmers and develop appropriate solutions through regular training and contact with research. This corroborate with a study carried out by Bassey (2016) on the assessment of farmers preference for agricultural extension in Nigeria which revealed that $(75 \%)$ of the respondents in North Central Zone of Nigeria have formal education ranging from primary to tertiary level of education, though majority (49.33\%) have only primary education, which still is better than having no training at all.

Table 1: Mean distribution of the respondents on the extent to which professional operations of unified agricultural extension services have improved agro practices in the three geopolitical zones

\begin{tabular}{|c|c|c|c|c|c|}
\hline Principles of Professionalism & $\begin{array}{c}\begin{array}{c}\text { South- } \\
\text { South } \\
\text { (Rivers) }\end{array} \\
\begin{array}{c}\mathbf{n}=\mathbf{1 6 8} \\
\overline{\mathbf{x}} \mathbf{1}\end{array}\end{array}$ & $\begin{array}{c}\begin{array}{c}\text { South- } \\
\text { East } \\
\text { (Imo) } \\
\text { n }=168 \\
\bar{x} 2\end{array}\end{array}$ & $\begin{array}{c}\begin{array}{c}\text { South- } \\
\text { West } \\
\text { (Ondo) } \\
\mathbf{n}=168 \\
\overline{\mathbf{x} 3}\end{array}\end{array}$ & $\begin{array}{c}\text { All } \\
\text { Zones } \\
\text { Grand } \\
\text { Mean } \\
\mathbf{N}=\mathbf{5 0 4} \\
\overline{\mathbf{x}}\end{array}$ & Remarks \\
\hline $\begin{array}{l}\text { Professional operations in extension have } \\
\text { improved technological practices in your } \\
\text { area }\end{array}$ & 2.63 & 3.09 & 3.48 & 3.07 & $\begin{array}{l}\text { High } \\
\text { extent }\end{array}$ \\
\hline $\begin{array}{l}\text { Professional operations in extension aided } \\
\text { farmers to adopt a new technology }\end{array}$ & 2.63 & 3.07 & 3.38 & 3.03 & $\begin{array}{l}\text { High } \\
\text { extent }\end{array}$ \\
\hline $\begin{array}{l}\text { Professional operations in extension have } \\
\text { assisted in identifying production constraint } \\
\text { in the field }\end{array}$ & 2.17 & 3.07 & 3.38 & 2.87 & $\begin{array}{l}\text { Low } \\
\text { extent }\end{array}$ \\
\hline $\begin{array}{l}\text { Professional operations in extension has } \\
\text { developed appropriate solutions to solve the } \\
\text { identified problems in your area }\end{array}$ & 2.44 & 3.02 & 3.48 & 2.98 & $\begin{array}{l}\text { Low } \\
\text { extent }\end{array}$ \\
\hline
\end{tabular}


Vol. 06, No. 03; 2021

ISSN: $2456-8643$

\begin{tabular}{|c|c|c|c|c|}
\hline $\begin{array}{l}\text { Professional extension worker has acquired } \\
\text { continuous and full training. }\end{array}$ & 2.56 & 3.01 & 3.35 & 2.97 \\
\hline $\begin{array}{l}\text { Professional operations in extension have } \\
\text { assisted in the improving research and } \\
\text { development of agriculture }\end{array}$ & 2.23 & 3.05 & 3.35 & 2.88 \\
\hline $\begin{array}{l}\text { Professional operations in extension have } \\
\text { improved the Unified Agricultural } \\
\text { Extension Services }\end{array}$ & 2.19 & 3.05 & 3.35 & 2.86 \\
\hline
\end{tabular}

The ANOVA result on the extent to which professional operations of Unified Agricultural Extension Services (UAES) has improved agro practices in the study areas (Table 2) indicated that $(\mathrm{F}$-cal $=110.36)$ and $(\mathrm{F}$-crit $=3.68)$ at a probability level less than 0.05 . Since F-cal is greater than the critical value, the null hypothesis which stated that there is no significance difference in the professional operations of Unified Agricultural Extension Services among the three geopolitical zones was rejected, meaning that professional operations of the Unified Agricultural Extension Services has not improved agro practices in all the geopolitical zones in southern Nigeria as shown in table 1. This means that extension programmes and services in these three geopolitical zones may be varying in terms of approaches used, objectives pursued, coordination and monitoring of extension works in these zones.

Table 2: ANOVA result on the extent to which professional operations of Unified Agricultural Extension Services have improved agro practices in the three geopolitical zones of southern Nigeria.

\begin{tabular}{|lcccccc|}
\hline Source of Variation & SS & Df & MS & F-cal & F-crit & Remarks \\
\hline Between Groups & 3.18 & 2 & 1.59 & & & \\
Within Groups & 0.22 & 501 & 0.01 & & & \\
Total & 3.40 & 503 & & $\mathbf{1 1 0 . 3 6}$ & $\mathbf{3 . 6 8}$ & S \\
\hline
\end{tabular}

Source: Field Survey, 2019

$\mathrm{S}$ - Means significant at $\mathrm{P}<0.05 \%$

The result (Table 3), showed that the high cost of funding technologies has limited the effectiveness of Unified Agricultural Extension Service in the study areas (GM =3.89) and that the deficiency in FNT, MTRM, OFAR trainings and other meetings have affected the effectiveness of Unified Agricultural Extension Services in the study areas $(\mathrm{GM}=3.35)$. It also showed that lack of mobility and other incentives hampered the effectiveness of Unified 
Agricultural Extension Service in the three geopolitical zones $(\mathrm{GM}=3.14)$ even though the effects was more in South-South zone $(\mathrm{M}=3.61)$ and low in both South-East and South-West $(\mathrm{M}=2.98$ and $\mathrm{M}=2.84$ respectively). It further showed that extension staff does not receive the regular training required to continuously upgrade their professional abilities to meet the technological demands of farmers $(\mathrm{GM}=2.86)$. These findings corroborates with the World Bank, (2004) who reported that the effectiveness of UAES has been on a descending lane as a result of lack of trainings, reduction in the number of extension workers and other field staff which have contributed to poor delivery of extension services.

Table 3: Mean distribution of the respondents on the extent to which unified agricultural extension services are effective in the three geopolitical zones of southern Nigeria

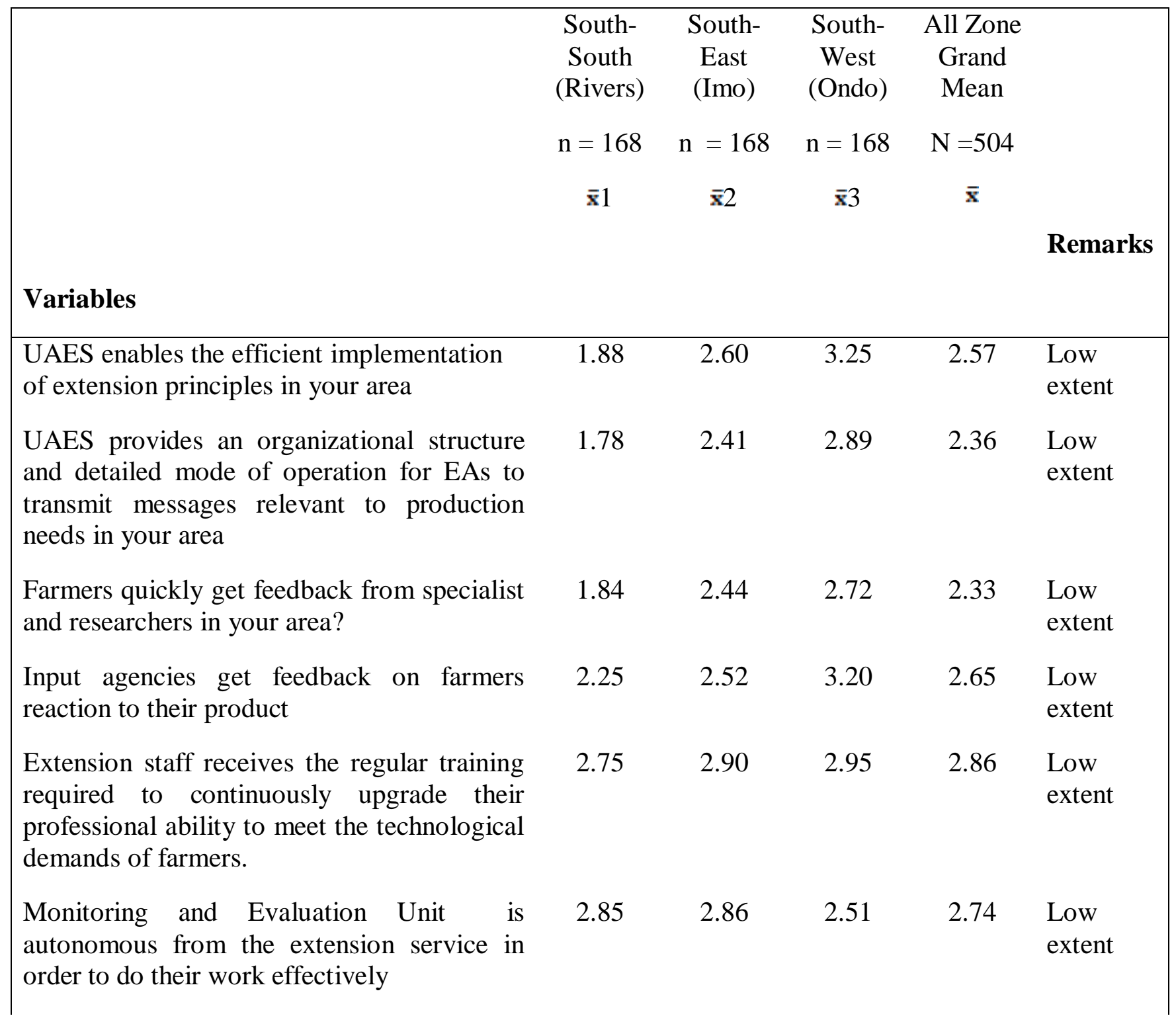


Vol. 06, No. 03; 2021

ISSN: $2456-8643$

Contact farmers are represented and adequate in your area.

Cost of funding technologies has limited the effectiveness of Unified Agricultural Extension Service

To what extent has deficiency in staff quality and poor development of a responsive attitude among staff inhibited the effectiveness of Unified Agricultural Extension Service

Deficiency in FNT, MTRM, OFAR trainings and other meetings has affected the effectiveness of Unified Agricultural Extension Service

Teaching aids used in educating the farmers

Lack of mobility and other incentives hampered the effectiveness of Unified Agricultural Extension Service

Effectiveness of Unified Agricultural Extension Service improved your farm yield
2.49

4.53

3.83

2.63

2.97

2.69

Low extent

3.31

3.89

High

extent

2.48

2.49

2.89

2.62

Low extent

3.38

3.33

3.35

High extent

\subsection{5}

2.43

2.37

2.41

Low extent

3.61

2.98

2.84

3.14

High extent

2.46

2.75

2.46

Low extent

Source: Field Survey, 2020

Critical Mean $=3.00$

The test result on the extent to which Unified Agricultural Extension Services are effective in the study areas $($ Table 4$)$ showed an $(\mathrm{F}-\mathrm{cal}=0.34)$ and $(\mathrm{F}-\mathrm{crit}=3.28)$ at probability level greater than $0.05 \%$. Since F-cal is less than the critical value, the null hypothesis which states that there is no significant difference in the knowledge gaps to the effectiveness of Unified Agricultural Extension Services among the three geopolitical zones under study was accepted, which is an indication that knowledge gaps to effectiveness of Unified Agricultural Extension Services among the three geopolitical zones in southern Nigeria do not exist, rather, it is the approach used, objectives pursued, coordination and monitoring of extension works that may be fronting any difference in the operations of the Unified Agricultural Extension Services in these zones.

Table 4: ANOVA Result on the extent to which unified agricultural extension services are effective in the three geopolitical zones of southern Nigeria

\begin{tabular}{|lcccccc|}
\hline Source of Variation & SS & Df & MS & F-cal & F-crit & Remarks \\
\hline Between Groups & 0.21 & 2 & 0.10 & & &
\end{tabular}




\begin{tabular}{|lllllll|}
\hline & & & & & & \\
Within Groups & 10.00 & 501 & 0.30 & & & \\
Total & 10.21 & 503 & & $\mathbf{0 . 3 4}$ & $\mathbf{3 . 2 8}$ & NS \\
\hline
\end{tabular}

Source: Field Survey, 2020

NS - Means significance at $\mathrm{P}>0.05 \%$

\section{CONCLUSION}

From the findings, it showed that knowledge gaps do not exist in the unified agricultural extension services among the three geopolitical zones in the southern Nigeria. Rather, it is the approach used, objectives pursued, coordination and monitoring of extension works that may be fronting any difference in the operations of the Unified Agricultural Extension Services in these zones, owing to the fact that Agricultural Development Project of different regions or zones make different policies, pursue different objectives and with different levels of workers execute agricultural extension programmes or services that suits their zones.

\section{RECOMMENDATIONS}

Based on the findings of the study, the following recommendations are:

1. Professional operations in the Unified Agricultural Extension Services should be encouraged in

The South-South geopolitical zone in order to, at least be on the same page with the other zones

In Nigeria.

2. Fortnight Training (FNT) sessions of the extension agents should be emphasized and properly Monitored to achieve continuous uniformity in extension operations in the study areas.

3. A unified extension package involving the State Ministries of Agriculture, non-

Governmental agro agencies, extension professionals and the farmers should be developed to encourage uniformity in extension method and service delivery in Nigeria.

\section{REFERENCES}

Adedoyin, F. S. (2004). Policy issues and legislation in agricultural extension delivery in a democratic and parag economy. Proceedings of the 9th Annual National Conference of the Agricultural Extension Society of Nigeria.

Agbor, T. Torima, P. I. \& Imbur, E.N. (2013). Lessons from implementation of Nigeria's past national agricultural programs for the transformation agenda. American journal of research communication, 1(19) 78-83.

Amalu, U. C. (1998). Agricultural Research and Extension Delivery System in Sub Saharan Africa; Calabar: The University of Calabar.

Asiabaka C. C. (2008). The need for agricultural extension policy in national development. Keynote address presented at the 13th Agricultural Extension Society of Nigeria (AESON). 
Vol. 06, No. 03; 2021

ISSN: $2456-8643$

Bassey, J. I., (2016). International journal of agricultural extension and rural development studies 3(4). 59-86. Published by European centre for research training and development UK (www.eajournals.org).

Benor, D. \& Baxter, M. (1984). Training and Visit extension. Washington D.C. The World Bank publication.

Feder, G. \& Slade, R. (1986). The impact of agricultural extension: The training and visit system in India. World Bank Research Observer, 1(2), 139-161.

Falusi A. O, Olayide S. O. (1980). Agriculture inputs and the small renew, Nigeria in J. O. Olayide J. A. Eweka and V. E. Bello Osagie (eds) Nigeria Small Renew. 67 - 86.

Garforth, C. (2004). Demand-led approaches, in Rivera, W., \& Alex, G., eds, Demand- Driven Approaches to Agriculture Extension. Case Studies of International Initiatives, Agriculture and Rural Development Discussion Paper 10, Extension Reform for Rural Development. World Bank Publications, Vol 3, World Bank, Washington, DC. 1-6.

Idachaba F. S. (1980). Concept and Strategies of Integrated Rural Development Lessons from Nigeria. Food Policy Technical Research Paper No. 1, Department of Agricultural Economics, University of Ibadan. 23-24.

Kankara, I. A. and Darma, M. R (2016). A Review of Gold Metallurgeny in Nigeria. Int'l Journal of Research in Chemical, Metallurgical and Civil Engg. (IJRCMCE) 3(2). ISSN 2349-1442 EISSN 2349-1450.

Ladele, A. A. \& Chah J. M. (2014). Sampling techniques in agricultural extension research. A Guide to Research in Agricultural Extension. Agricultural Society of Nigeria. 35 53.

Madukwe, M. C. (1995). Agricultural extension system and strategies in Nigeria rural development. A Guide to Research in Agricultural Extension. Agricultural Extension Society of Nigeria. 1-8.

Moore, M. \& Mac Cabe K. (2006). Adolescent back pain and associated backpack loading, locker use, online textbook alternatives. Published October, 2006.

National Bureau of Statistics, (2009). Labour Force survey. Abuja: NBS.

Obibuaku, L. O. (1983). Agricultural extension as a strategy for agricultural transformation. University of Nigeria Press, Nsukka. 119.

Odinwa, A. B., Isife, B. I. \& Nlerum, F. E. (2019). Analysis of the extension needs of yam farmers for increased productivity in Rivers and Imo States, Nigeria. International Journal of Agriculture, Environment and Bioresearch. 4(6). $162-178$.

Robert, C. \& Robert, T., (2003). Changing incentives for agricultural extension. A review of privatized extension network. 132 .

Udiandeye, C. U. (2017). Current issues in agricultural extension and technology. Keynote at the Department of Agricultural Hamisu et al., AJAAR, 1(3): 1-8, Article no.AJAAR.34875.

Unamma, R. P. A., Onwudike, O. C., Uwaegbute, A. C., Edega, H. O., Nwosu, A. C., (eds.) (2004). Linkage Strategy for Sustainable Agriculture in Nigeria-Research-Extension-FarmerInput-Linkage System (REFILS). Michael Okpara University of Agriculture, Umudike, Nigeria. 213. 
William, S. K. T. \& Fenley J. M., (1984). Evaluation and monitoring process in extension. In William, S.K.T., (1989). Extension services within the strategy of agricultural development in Nigeria in the 1990s. Published by ARMTI, Ilorin Nigeria.11-30.

World Bank (2004). Project coordinating unit. Annual report on agricultural extension service delivery. 